\title{
Socio-demographic Profile of Patients Admitted in Thalassemia Care Center of Chattogram Maa Shishu-O-General Hospital
}

\author{
Tanuka Barua ${ }^{1 *}$ \\ Aparup Kanti Das ${ }^{2}$ \\ Razia Sultana ${ }^{3}$ \\ Dhananjoy Das ${ }^{1}$ \\ Mahmood A. Chowdhury Arju'
}

'Department of Paediatrics

Chattogram Maa-O-Shishu Hospital Medical College Chattogram, Bangladesh.

${ }^{2}$ Department of Paediatrics Boalkhali Thana Health Complex, Boalkhali Chattogram, Bangladesh.

${ }^{3}$ Department of Pathology Chattogram Maa-O-Shishu Hospital Medical College Chattogram, Bangladesh.

*Correspondence to:

Dr Tanuka Barua

Associate Prosessor

Department of Paediatrics

Chattogram Maa-O-Shishu Hospital Medical College

Chattogram, Bangladesh.

Mobile : +8801821654937

Email: tanukadr@gmail.com

Date of Submission : 03.11.2019

Date of Acceptance ： 10.12 .2019

www.banglajol.info/index.php/CMOSHMCJ

\begin{abstract}
Background: Thalassemia is the most common hemoglobin disorder in the world including Bangladesh. Population migration and intermarriage between different ethnic groups have had a major impact on disease epidemiology. To observe the prevalence and specturm of thalassemia as well as demographic and social factors of thalassemia patients.
\end{abstract}

Materials and methods: This descriptive cross-sectional study was conducted in the Thalassemia Care Center of Chattogram Maa Shishu-O-General Hospital, Chattogram from July, 2013 to June, 2014. Parents of 70 thalassemia patients aged 2-18 years interviewed with a formulated questionnaire based on social and demographic characteristics. Data were analyzed by both manually and by SPSS-18.

Results: Mean age of patients was 6 years ( \pm 3.66). Near about half of patients (40\%) were diagnosed at the age less than 5 years. Mean age of diagnosis was 1.6 years ( $\pm 1.53 \mathrm{SD}$ ). Majority of patients belonged to lower middle class (42.9\%) with male predominance (62.9\%). A good number of patients (22.8\%) were not engaged in any educational activity. Mean annual income of family was 262000 taka/year \pm 245477.35 (USD $3324.87 \pm 3115.19$ ). Mother contributed to annual income in only $4.7 \%$ families. The percentage of $\mathrm{Hb} E / \beta$ thalassemia was the highest (54.4\%) followed by $\beta$ thalassemia major (37.1\%) and $H b$ E disease (4.3\%). Male predominance was found in every type of thalassemia. Half of the thalassemia major patients were diagnosed during infancy and majority (60.53\%) of $\mathrm{Hb} \mathrm{E/ \beta}$ thalassemia patients were diagnosed at the age less than 5 year.

Conclusion: A nation-wide screening program should be carried out to address the carrier status of population at risk. There may be further analysis regarding clinical diversity of thalassemia.

Key words: Thalassemia; Socio-demographics; Pattern of thalassemia.

\section{INTRODUCTION}

Thalassemia is the most common hemoglobin disorder in the world. It comes from a Greek word "Thalas" meaning the sea and "emia" for blood. The word came into use as thalassemia was originally described in countries bordering the Mediterranean $\mathrm{Sea}^{1}$. It is particularly associated with people of Mediterranean, Indian subcontinent, Middle-east, Southern China as well as countries along the north coast of Africa and in the South America with highest carrier rate in Cyprus (14\%) and South-east Asia $^{2,3}$. Population migration and intermarriage between different ethnic groups has introduced thalassemia in almost every country of the world including Northern Europe where thalassemia was previously absent ${ }^{4}$. It has been estimated that about $1.5 \%$ of the global population are carrier of beta thalassemia with about 60,000 symptomatic individual born annually with great majority in the developing world ${ }^{4,5}$. 
In South-East Asia, the common combination of beta thalassemia with abnormal hemoglobin, $\mathrm{Hb} \mathrm{E} / \beta$ thalassemia is the most prevalent where carrier frequency is around $50 \%{ }^{5}$ The estimated prevalence is $16 \%$ in people from Cyprus, $1 \%$ in Thailand and $3-8 \%$ in populations from Bangladesh, China, India, Malaysia and Pakistan. ${ }^{6}$ There are about 65,000-67,000 $\beta$ thalassemia patient in India and approximately 30 million carriers of $\beta$ thalassemia with a mean prevalence of $3.3 \%{ }^{7}$. In Pakistan, an estimated 5000-9000 children with $\beta$ thalassemia are born per year and the estimated carrier rate is $5-7 \%{ }^{8}$. In Bangladesh though the exact data regarding the prevalence and spectrum of hemoglobinopathies is not known, a conservative WHO report estimates that $3 \%$ of total population (About 3.6 million people) is carrier of $\beta$ thalassemia and $4 \%$ are carriers of $\mathrm{Hb} \mathrm{E}$ in Bangladesh and more than two thousand thalassemic children are born every year ${ }^{6,9}$ and the most common form of $\mathrm{Hb}$ disorder is $\mathrm{Hb} / \beta$ thalassemia followed by $\mathrm{Hb} \mathrm{E}$ type and $\beta$ thalassemia major ${ }^{9,10}$.

This chronic disease particularly causes major social and financial burdens on patients, families and health care system ${ }^{11}$. Thalassemia is becoming a burden for our country. As the asymptomatic carrier is the reservoir the diseases and the disease are continues to increasing ${ }^{12}$. There is limited data to provide a true picture and incidence varies according to marriage practices and culture. This study was conducted to assess socio-economic and demographics profile of thalassaemic patients by which we can provide information to health authority regarding the spectrum and other related messages to take necessary steps.

\section{MATERIALS AND METHODS}

It was a descriptive cross-sectional study conducted at Chattogram Maa Shishu-O-General Hospital, Chattogram from July, 2013 to June, 2014. 70 patients aged 2-18 years registered at Thalassaemia Care Centre of Chattogram Maa Shishu-OGeneral Hospital, Chattogram were included in this study. Study work was approved by the Ethical Review Committee of Chattogram Maa Shishu-O-General Hospital, Chattogram. Informed written consent was obtained from any of parents or a family member of each patient. Detailed study related information was read out and explained in the local language from a printed hand out. Parents were interviewed according to a formulated questionnaire covering demographic, social and economic variables. Data were checked and analyzed manually with the help of calculator and software SPSS 18.0.

\section{RESULTS}

Among 70 patients, most of the patients were in $<5$ years age group followed by 5-10 years age group with male predominance $(62.9 \%)$. Mean age was 6 years $( \pm 3.66)$. Majority of patients were from rural background (54.9\%) and were belonged to lower middle class $(42.9 \%)$ followed by lower class (31.4\%) (Table I). Most of the child was diagnosed as thalassemic at the age of $1-5$ years group (40\%) followed by 6 month-12 months (32.9\%), <6 months (22.8\%), 5-10 years age group (4.3\%) and mean age of diagnosis was 1.6 years $( \pm$ 1.53 SD) (Table I). About 22.8\% were not engaged in any educational activity, 34.3\% $(n=24)$ were studied in primary education, $10 \%$ in secondary level and $32.9 \%$ were below the school age as we considered the age completed $4^{\text {th }}$ years as age of beginning of school. Majority were belonged to lower middle class followed by lower class (31.4\%). 5.7\% family had another affected child and $7.1 \%$ had a child died previously of thalassemia (Table I).

Father was the only earning member in majority family. Mother contributed to total annual income in 5.7\% family. Total annual income ranged from 24000 to 1320000 taka/year (USD 304.57 to USD 16751.27) and only in $15.7 \%(n=11)$ families it was more than 400000 taka/year (USD >5076.14). Mean annual income was 262000 taka/year \pm 245477.35 (USD $3324.87 \pm$ 3115.19) (Table I). Mother's income ranged between 16000240000 taka/year (USD 203.05-3045.69) (Table II) and on an average $28.19 \% \pm 25.60 \%$ of annual income was contributed by mother (Table III).

Table I : Patient's demographics $(\mathrm{n}=70)$

\begin{tabular}{|c|c|c|}
\hline Variables & Frequency & Percentage $(\%)$ \\
\hline \multicolumn{3}{|l|}{ Age in Groups } \\
\hline$<5$ Years & 38 & 54.3 \\
\hline $5-10$ Years & 23 & 32.9 \\
\hline $10-15$ Years & 7 & 10.0 \\
\hline$>15$ Years & 2 & 2.8 \\
\hline \multicolumn{3}{|l|}{ Gender } \\
\hline Male & 44 & 62.9 \\
\hline Female & 26 & 37.1 \\
\hline \multicolumn{3}{|l|}{ Locality } \\
\hline Rural & 38 & 54.3 \\
\hline Urban & 32 & 45.7 \\
\hline \multicolumn{3}{|l|}{ Age of Diagnosis } \\
\hline$<6$ Months & 16 & 22.8 \\
\hline $6-12$ Months & 23 & 32.9 \\
\hline $1-5$ Years & 28 & 40.0 \\
\hline $5-10$ Years & 3 & 4.3 \\
\hline \multicolumn{3}{|l|}{ Level of Education } \\
\hline Not Reached at School Age & 23 & 32.9 \\
\hline Nil & 16 & 22.8 \\
\hline Primary & 24 & 34.3 \\
\hline Secondary & 7 & 10.0 \\
\hline \multicolumn{3}{|l|}{ Socio-economic Status } \\
\hline Lower Class & 22 & 31.4 \\
\hline Lower Middle Class & 30 & 42.9 \\
\hline Upper Middle Class & 15 & 21.4 \\
\hline Upper Class & 3 & 4.3 \\
\hline \multicolumn{3}{|c|}{ Family History of Thalassemia } \\
\hline No Sibling Affected & 51 & 72.9 \\
\hline One Sib Affected & 4 & 5.7 \\
\hline No Sibling & 15 & 21.4 \\
\hline
\end{tabular}




\section{History of Sibling Death}

One Sib Death

No Death

5

65

7.1

Parent's employment

Only Father

Both Father \& Mother

66

4

94.3

Annual income of parent's

(Taka/Year)

$\begin{array}{lrr}<50000 & 3 & 4.3 \\ 50000-100000 & 12 & 17.1 \\ 100000-200000 & 20 & 28.6 \\ 200000-300000 & 17 & 24.3 \\ 300000-400000 & 7 & 10.0 \\ >400000 & 11 & 15.7\end{array}$

- Age of Patients (Mean \pm SD (Range): $6.06 \pm 3.66$ Years $(1.9-17.0)$

- Age of Diagnosis (Mean \pm SD (Range): $1.60 \pm 1.53$ Years $(0.2-7.0)$

$\rightarrow$ Annual Income -

Mean \pm SD (Range): BDT $262000.00 \pm 245477.35$ (BDT 24000-1320000)

: USD $3324.87 \pm 3115.19$ (USD 304.57-16751.27)*

* 1 dollar $=78.80$ taka as per exchange rate on July, 2016 BDT $=$ Bangladeshi taka, USD $=$ US dollar

Table II : Contribution of mother's income to total annual income $(\mathrm{n}=4)$

\begin{tabular}{llll}
$\begin{array}{l}\text { No. of } \\
\text { Patients } \\
(\%)\end{array}$ & Annual Income & $\begin{array}{l}\text { Range } \\
\text { BDT } / \text { Year } \\
\text { (USD } / \text { Year) }\end{array}$ & $\begin{array}{l}\text { Mean } \pm \text { SD } \\
\text { BDT } / \text { Year } \\
\text { (USD } / \text { Year) }\end{array}$ \\
$1(25.0)$ & BDT $<50000$ & & \\
$0(0.0)$ & BDT 50000-100000 & BDT 16000-240000 & BDT 139000.00 \\
& & (USD 203.05-3045.69) & $\begin{array}{l} \pm 95519.63 \\
\text { (USD 1763.96 }\end{array}$ \\
$1(25.0)$ & BDT 100000-200000 & & $\pm 1212.18)$ \\
$2(50.0)$ & BDT $>200000$ & & \\
\hline
\end{tabular}

- BDT $/$ Year $=$ Bangladeshi Taka per year

- USD / Year = US Dollar per year

The most common pattern of thalassemia was $\mathrm{Hb} \mathrm{E} / \beta$ thalassemia $(54.4 \%)$ followed by $\beta$ thalassemia major $(37.1 \%)$, $\mathrm{Hb} \mathrm{E}$ disease $(4.3 \%), \mathrm{Hb} \mathrm{H}$ disease $(2.8 \%)$ and $\mathrm{Hb} \mathrm{S} / \delta$ Thalassemia (1.4\%) (Table IV). Male predominance was noted in every type of thalassemia (Table IV). Most of the $\mathrm{Hb} \mathrm{E} / \beta$ Thalassemia patients $(60.53 \%)$ were diagnosed at 1 to 5 years of age and half of the $\beta$ Thalassemia major patients were diagnosed at 6 month to 12 months age group (Table V).

Table III : Pattern of thalassemia $(n=70)$

\section{Variables}

$\mathrm{Hb}$ E/ $\beta$ Thalassemia

$\beta$ Thalassemia major

$\mathrm{Hb}$ E Disease

$\mathrm{Hb} H$ Disease

$\mathrm{Hb} \mathrm{S} / \delta$ Thalassemia

\section{Frequency}

38

26

3

2

1
Percentage (\%)

54.4

37.1

4.3

2.8

1.4
Table IV : Distribution of different type of thalassemia according to $\operatorname{sex}(\mathrm{n}=70)$

\begin{tabular}{lcc} 
Variables & Male $(\mathbf{n}=44)$ & $\begin{array}{l}\text { Female }(\mathbf{n}=\mathbf{2 6}) \\
\text { No }(\%)\end{array}$ \\
\hline $\mathrm{Hb}$ E/ $\beta$ Thalassemia $(\mathrm{n}=38)$ & $25(65.79)$ & $13(34.21)$ \\
$\beta$ Thalassemia Major $(\mathrm{n}=26)$ & $15(57.69)$ & $11(42.31)$ \\
$\mathrm{Hb}$ E Disease $(\mathrm{n}=3)$ & $2(66.67)$ & $1(33.33)$ \\
$\mathrm{Hb} \mathrm{H}$ Disease $(\mathrm{n}=2)$ & $1(50.00)$ & $1(50.00)$ \\
$\mathrm{Hb} \mathrm{S} / \delta$ Thalassemia $(\mathrm{n}=1)$ & $1(100.00)$ & $0(0.00)$ \\
\hline
\end{tabular}

Table V : Distribution of different type of thalassemia according to age of diagnosis $(\mathrm{n}=70)$

\begin{tabular}{|c|c|c|c|c|c|c|c|c|}
\hline & \multicolumn{2}{|c|}{$\begin{array}{c}<6 \\
\text { Months }\end{array}$} & \multicolumn{2}{|c|}{$\begin{array}{c}6-12 \\
\text { Months }\end{array}$} & \multicolumn{2}{|c|}{$\begin{array}{c}1-5 \\
\text { Years }\end{array}$} & \multicolumn{2}{|c|}{$\begin{array}{l}5-10 \\
\text { Years }\end{array}$} \\
\hline & No & $\%$ & No & $\%$ & No & $\%$ & No & $\%$ \\
\hline $\mathrm{Hb} \mathrm{E} / \beta$ Thalassemia $(\mathrm{n}=38)$ & 5 & 13.16 & 8 & 21.05 & 23 & 60.53 & 2 & 5.26 \\
\hline$\beta$ Thalassemia Major $(\mathrm{n}=26)$ & 10 & 38.46 & 13 & 50.0 & 3 & 11.54 & 0 & 0.0 \\
\hline $\mathrm{Hb}$ E Disease $(\mathrm{n}=3)$ & 1 & 33.33 & 1 & 33.33 & 0 & 0.0 & 1 & 33.33 \\
\hline $\mathrm{Hb}$ H Disease $(\mathrm{n}=2)$ & 0 & 0.0 & 1 & 50.0 & 1 & 50.0 & 0 & 0.0 \\
\hline $\mathrm{Hb} / \delta$ Thalassemia $(\mathrm{n}=1)$ & 0 & 0.0 & 0 & 0.0 & 1 & 100.0 & 0 & 0.0 \\
\hline
\end{tabular}

\section{DISCUSSION}

Unlike some other studies where common age group was $<10$ years, we found, most of our patients $(54.3 \%)$ were in $<5$ years age group with male preponderance $(62.9 \%)$ and mean age was 6 years $( \pm 3.66)^{13,14}$. Male preponderance was also reported by other studies ${ }^{14,15,16}$. Similar to Bandyapahyay B et al we found only $2.8 \%$ patients were beyond 15 years ${ }^{17}$. In most cases, thalassemia was diagnosed at $<5$ years. This findings is consistent with to Mallik S et al, Riewpaiboon A et $\mathrm{al}^{14,18}$. Mean age of diagnosis of thalassemia of our patients was 1.6 years $( \pm 1.53)$. But in Thailand and Iran the average age of diagnosis of thalassemia was 9.52 years and 4 years respectively ${ }^{18,19}$. This may be due to clinical diversity and type of thalassemia.

In Iran $44 \%$ patients had family history of thalassemia but we had only $5.7 \%$ patients with another thalassemic $\mathrm{sib}^{19}$. This may be due to that in Iran the study was carried out nationwide involving a large group of population but we conducted the study in Thalassemia Care Center of one hospital where only small group of patients of the locality are registered and this study was conducted over one year only. Disease burden might be doubled or more of those family having another thalassemic $\mathrm{sib}$ that is really difficult for them to continue full treatment of their child.

We found one third $(32.9 \%)$ patients did not reach the age of beginning of school as we consider the $4^{\text {th }}$ years completed age as the age of entrance of school. Another one third (34.3\%) were on primary education, $10 \%$ were on secondary education. More than $75 \%$ patients had completed primary education in Kolkata $(75 \%)$, Iran $(78.9 \%)$ that is quite higher than our findings ${ }^{14,19}$. A good percentage $(22.8 \%)$ of our patints were not engaged in any educational activity that is consisted with other studies conducted in our neighbor countries like Kolkata 
(37\%), Pakistan $(66.7 \%)$, Western India $(18 \%)^{14,20,21}$. We should encourage our parents to start or continue their child's education despite regular blood transfusion and other treatment related stress of a thalassemia patient.

Most of our patients $(42.9 \%)$ were from lower middle socioeconomic status whereas most of the patients in Kolkata, Pakiatan, Western India were from poor family ${ }^{14,15,20,21}$. In Pakistan, 91.7\% had income $<$ Rs 5000/month, average father's income was Rs 28512 per annum and there was $<5$ patients whose father's income was $>$ Rs $6000 /$ month $^{15,20}$. In contrast, $28.6 \%$ of our family had annual income between 10000 to 200000 taka/year (USD 126.90 to USD 2538.07) 4.3\% had $<50000$ taka/year (USD <634.52) and only $15.7 \%$ had income $>400000$ taka/year (USD >5076.14). Average annual income was 262000 taka/year \pm 245477.35 (USD $3324.87 \pm 3115.19$ ). In Iran main income provided for patients and their families was the parents $(78 \%)$, patient's husband/wives $(8 \%)$, patients himself/herself $(7 \%)$ whereas in our study in cent percent cases main income source was the father ${ }^{19}$. Our findings are consistent with the findings of Pakistan in where majority of the father was the only earning members of the family and most of the mothers were housewife ${ }^{22}$. Mother contributed to annual income only in $5.7 \%$ cases and of them in $50 \%$ family mother contributed up to $50 \%$ of annual income. No patient of our study was engaged in earning. This is because we enrolled patients belongs to pediatric age group aged 2-18 years only, none of them was married or engaged in any job.

The percentage of $\mathrm{Hb} \mathrm{E} / \beta$ thalassemia was the highest (54.4\%) followed by $\beta$ thalassemia major (37.1\%) and $\mathrm{Hb} \mathrm{E}$ disease (4.3\%). This is supported by other studies conducted in our country like Mannan A et al, Uddin MM et al implies that $\mathrm{Hb}$ $\mathrm{E} / \beta$ thalassemia is the most common type thalassemia in our country ${ }^{16,23}$. Worldwide and also in asia-pacific region $\mathrm{Hb} \mathrm{E} / \beta$ thalassemia is one of the most frequent thalassemia ${ }^{24,25}$. Unlike Mannan A et al we did not find any thalassemia intermedia or $\mathrm{Hb} \mathrm{E}$ trait patient that may be due to mild variety in nature and occasional need of blood transfusion of these type for which these were missed as we enrolled only those patients who had history of at least 1 year blood transfusion ${ }^{16}$. Similar to Mannan A et al male predominance was found in every type of thalassemia ${ }^{16}$. These may be due to gender inequality in care seeking behavior of parents for chronic illness that is still prevalent in our society. Similar to other studies we observed that most of the beta thalassemia major patients were diagnosed as thalassemia before 1 years of age but most of $\mathrm{Hb} \mathrm{E} / \beta$ thalassemia patients were diagnosed at the age ranged 1 to 5 years $^{26,27}$. This also represent clinical diversity of different type thalassemia and the earlier clinical presentation of beta thalassemia major than $\mathrm{Hb} \mathrm{E} / \beta$ thalassemia.

\section{LIMITATIONS}

This study was conducted only in thalassemia care center of Chattogram Maa Shishu-O-General Hospital, Chattogram. The sample size was small and study period was only one year.

\section{CONCLUSIONS}

This study reveals that the most common pattern of thalassemia are $\mathrm{Hb}$ E $\beta$ thalassaemia followed by $\beta$ thalassaemia which represents an overall prevalence of thalassemias of the country. Population migration may explain the prevalence of these patterns. Earlier age of onset in majority cases reflects the severe form of thalassemia. Severe forms are widely distributed in both $\mathrm{Hb} \mathrm{E} \beta$ thalassaemia and $\beta$ thalassaemia. It is necessary to study more about the reason of clinical diversity for better management and an accurate population frequency data are needed for the control of thalassemia. We have not studied the correlation of clinical diversity with genetic mutation. There may be further analysis in genetic studies identifying the reasons of phenotypic diversity.

\section{DISCLOSURE}

All the authors declared no competing interest. 


\section{REFERENCES}

1. Angastiniotis M, Modell B. Global epidemiology of hemoglobin disorders. Ann NY Acad Sci. 1998;850:251-269.

2. Flint J, Harding RM, Boyce AJ, Clegg JB. The population genetics of the hemoglobinopathis. Ballier's Clinical Hematology. 1998;11:1-50.

3. Guideline for the clinical management of Thalassemia. Thalassemia International Federation. $2^{\text {nd }}$ edition, 2008. (http://www.thalassemia.org.cv/).

4. Colah R, Gorakshakor A, Nadkarni A. Global burden, distribution and prevention of beta-thalassemia and hemoglobin E disorders. Expert Rev Hematol. 2010;3(1):103-117.

5. Galanello R and Origa R. Review: Beta-thalassemia. http://www.ojrd.com/content/5/1/11, published - (Accessed on 21 May, 2010).

6. WHO guidelines for control of hemoglobin disorders. Unpublished document WHO/HDP/HB/GL/94.

7. Center for Education. Mission Thalassemia. http://www.cedranchi.com/index.htm (Accessed on 14th Jan, 2009).

8. Ansari SH, Shamsi TS, Ashraf M. Molecular epidemiology of beta-thalassemia in Pakistan: Far reaching implications. Indian J Hum Genet 2012;18(2):193-197.

9. Khan WA. Thalassemia in Bangladesh. Dhaka Shishu (Child) Hospital Journal. 1999;15:42-44.

10. Khan WA, Banu B, Amin SK. Prevalence of beta-thalassemia trait and Hb-E trait in Bangladesh school children and health burden of thalassemia in our population. Dhaka Shishu (Child) Hospital Journal. 2005;21:1101-1107.

11. Prasomsuk S, Jetsrisuparp A, Ratanasiri T, Ratanasiri A et al. Lived experiences of mothers caring for children with thalassaemia major in Thailand. JSPN. 2007;12(1):13-23.

12. Das R. Micromapping the frequencies of beta-thalassemia and sickle cell anemia in India: Away forward to plan control strategies. Indian $\mathbf{J}$ Hum Genet. $2012 ; 18(2): 148-149$.

13. Uddin MK, Aziz MA, Bhuya MF, Dipta TF, Begum M, Yunus ABM et al. Electrophoretic pattern of hereditary haemoglobin disorders in Bangladesh. Medicine Today. 2009;21(2):58-60.

14. Mallik S, Chatterjee C, Mandal PK, Sardar JC, Ghosh P and Manna N. Expenditure to treat thalassemia: An experience at a tertiary care hospital in India. Iran J Public Health. 2010;39(1):78-84

15. Qumruzzaman and Salahuddin. Association between the education and thalassemia- A statistical study. Pak J Stat Oper Res. 2006;11(2):103-110.

16. Mannan A, Kawser J, Ahmed AMA, Sikder OF, Islam MJ, Chowdhury MA. A Demographic Approch for Understanding the Prevalence of beta Thalassemia Patterns and Other Hemoglobinopathies: Selective Study in Chittagong City Perspective. Asian J Biol Sci. 2013. ISSN 1996-3351 / DOI: 10.3923/ajbs.2013.

17. Bandyopadhyay B, Nandi S, Mitra K, Mandal PK, Mukhopadhayay S, Biswas AB. Comparative study on perceptions and practices among parents of thalassemic children attending two different institutions. Ind Medica. 2003;28(3) (copyright @ 2005 Indomedica).

18. Riewpaiboon A, Nuchpravoon I, Torcharus K, Indaratna K, Thavorncharoensap M and Ubol B. Economic burden of beta-thalassemia /Hb E and beta-thalassemia major in Thai children. BMC Res Notes. 2010;3:29 http://www.biomedcentral.com/1756-0500/3/29 ( accepted on January 30,2010$)$.

19. Sattari MR, Shoykhi D, Nikanfur A, Pourfeizi AH, Nanari M, Dolatkhah R et al. The finantial and social impact of thalassemia and $1^{\text {st }}$ treatment in Iran. Pharma Sci. 2012;18(3):171-176.

20. Arif F, Fayyaz J, Hamid A. Awareness among parents of children with thalassemia major. JPMA. 2008;58(11):621-624.

21. Jagdish PG, Palak TH, Harsha G. Awareness among parents of children with thalassemia major from Western India. Int J Med Sci Public Health. 2015;4(10):1356-1359

22. Rahaman S, Batool S, Qadir R. Socio economic status impact thalassemia child on families of Faisalabad district. Pak J of Appl Sci. 2002;2(2):202-205.

23. Uddin MM, Akhteruzzan S, Rahman T, Hasan AKM and Shekhar HU. Pattern of beta-thalassemia and other hemoglobinopathis: A crosssectional study studied in Bangladesh. ISRN Hematol. 2012.

24. Vichinky EP. Changing pattern of thalassemia worldwide. Ann NY Acad Sci. 2005;1054:18-24.

25. Viprakasit V, Gattermann N and Cappellini MD. Geographical variations in current clinical practice on transfusion and iron chelation therapy across various transfusion-dependent anemia. Blood Transfus. 2013;11(1):108-122.

26. Samarakoon PS and Nijesuriya AP. Thalassemia in Srilanka: Implications for future health of Asian population- Srilanka Thalassemia Study Group. Lancet. 2000;355:786-791.

27. Ward A, Caro JJ, Green TC, Huybrechts K, Arama A, Wait S et al. An international survey of patients with thalassemia major and their views about sustaining life-long desferrioxamine use. BMC Clin Pharmacol. 2002;2:3. 